This is an electronic reprint of the original article. This reprint may differ from the original in pagination and typographic detail.

Author(s): Kontinen, Tanja; Ojala, Arto

Title: Network ties in the international opportunity recognition of family SMEs

Year: $\quad 2011$

Version:

Please cite the original version:

Kontinen, T. \& Ojala, A. (2011). Network ties in the international opportunity recognition of family SMEs. International Business Review, 20 (4), 440-453.

All material supplied via JYX is protected by copyright and other intellectual property rights, and duplication or sale of all or part of any of the repository collections is not permitted, except that material may be duplicated by you for your research use or educational purposes in electronic or print form. You must obtain permission for any other use. Electronic or print copies may not be offered, whether for sale or otherwise to anyone who is not an authorised user. 


\title{
Network ties in the international opportunity recognition of family SMEs
}

\author{
Tanja Kontinen and Arto Ojala, University of Jyväskylä
}

\begin{abstract}
The importance of network ties is emphasized in the current literature on opportunity recognition. However, it is unclear how firms with limited bridging networks, such as family SMEs, recognize international opportunities through their network ties. In this case study we found that in gaining foreign market entry, those family SMEs that lack existing network ties recognize opportunities through weak ties formed in international exhibitions. The findings also indicate that rather than being proactive, family SMEs respond reactively to opportunities that emerge coincidentally. The trustfulness of the tie is important when they consider these opportunities and form new ties for internationalization. The nature of the cooperator appears to be more important than the target country. From these findings we develop five propositions that are intended to lead to further studies on this topic.
\end{abstract}

KEYWORDS: International opportunity recognition, network ties, international entrepreneurship, family SMEs.

\section{Introduction}

In the field of entrepreneurship, opportunity recognition has been regarded as a key aspect of the entrepreneurial process (Shane \& Venkataraman, 2000). Similarly, international opportunity recognition is acknowledged as an important element in understanding the internationalization behavior of firms (Chandra et al., 2009; Dimitratos \& Jones, 2005a, 2005b; Ellis, 2008; Johanson \& Vahlne, 2009; Oviatt \& McDougall, 2005; Zahra et al., 2005). Awareness of this aspect has led to recent interest in the precise means by which entrepreneurs identify and exploit new international opportunities (Chandra et al., 2009; Dimitratos \& Jones, 2005a; Ellis, 2008; Johanson \& Vahlne, 2009; Zahra et al., 2005).

It is well established that network ties are an important resource facilitating internationalization. Especially among small and medium-sized enterprises (SMEs) with limited resources for internationalization, network ties between firms have a significant role, as do the ties of individuals, especially managers or entrepreneurs (Crick \& Spence, 2005; Ellis, 2008; Hadjikhani et al., 2005). In several studies (Coviello, 2006; Crick \& Spence, 2005; Ghauri et al., 2003) such ties have been seen as major factors in initiating the internationalization process, with firms following their networks to foreign markets. This is consistent with the assumption in the network model of internationalization (Johanson \& Mattsson, 1988) that the network ties of firms act as a bridge to foreign markets.

According to Ellis (2008), international opportunity refers to the possibility of conducting exchange with new foreign partners. Exchanges can be conducted, for 
example, with customers, distributors, licensees, franchisees, contract manufacturers, or joint venture partners (Ellis, 2008), and it appears that the extent of an entrepreneur's network ties is positively related to opportunity recognition (Ozgen \& Baron, 2007; Singh, 2000). Such ties serve as conduits for the spread of information on new opportunities (Burt, 2004; Granovetter, 1973), and the ability to recognize novel opportunities may be determined by the reach of one's ties with others.

The aim of this study was to understand how the network ties of family SMEs function in recognizing opportunities to enter foreign markets. Family SMEs were selected as a target group for several reasons. Firstly, the proportion of family firms in the EU and US is about 85\% (IFERA, 2003) indicating the importance of family firms for local economies. Secondly, because of their survivability capital, family firms can sustain their business even during economic downturns (Sirmon \& Hitt, 2003). Thirdly, the internationalization of family-owned SMEs is different from that of non-family SMEs. Among family firms one can detect factors such as (i) limited managerial capabilities (Graves \& Thomas, 2006, 2008), (ii) different internationalization strategies (Fernandez \& Nieto, 2006; Gallo \& Pont, 1996; Graves \& Thomas, 2008; Zahra, 2003), (iii) limited networks (Graves \& Thomas, 2004). It also seems that internal network ties may be especially strong in family-owned businesses (Salvato \& Melin, 2008), but that their bridging network ties, outside the firm, are limited in comparison to non-family SMEs (Graves \& Thomas, 2004). Finally, it seems that there are differences in the way networks are established in the internationalization process of family SMEs (Graves \& Thomas, 2004) as compared to the network establishment of, for instance, rapidly internationalizing new ventures (Coviello, 2006). Hence, this study seeks to discover whether there are differences in the network formation of family SMEs as compared with SMEs in general, in the context of international opportunity recognition.

Although network ties have an essential role in the internationalization of SMEs, it is far from clear how family entrepreneurs recognize opportunities for foreign market entry, and in particular, how different kinds of network ties are used - and formed - in identifying such opportunities. To address these issues, the following questions are of interest:

1) What types of network ties do family entrepreneurs utilize in international opportunity recognition?

2) How does the strength of network ties explain the international opportunity recognition of family entrepreneurs?

3) What is the level of networking activeness of family entrepreneurs when they recognize the opportunity to enter a foreign market?

In addressing these questions, we selected as the target group of this research Finnish family SMEs operating in France. In so doing, we aimed to contribute to the network theory of internationalization by widening it towards family-owned SMEs. It was also our aim to respond to calls for more research on international opportunity recognition (Dimitratos \& Jones, 2005a; Ellis, 2008; Oviatt \& McDougall, 2005; Zahra et al., 2005), bearing in mind in particular the need for studies on the role of individual-level network ties in the recognition of opportunities for internationalization (Ellis, 2000, 2008). In addition, the study 
aimed to contribute to family business studies by investigating the poorly researched role of bridging networks when family firms enter foreign markets (Graves \& Thomas, 2004).

\section{Theoretical background}

In this section, we shall first look at the network model of internationalization, and in so doing introduce certain key terms related to networking. These are necessary steps, since the terminology related to networks is rather fragmented in the current literature. Nevertheless, the constructs we present are drawn from the literature on international opportunity recognition. Thereafter, we shall briefly discuss the internationalization of family SMEs. Thirdly, we shall present research related to opportunity recognition in general, and, further examine opportunity recognition specifically within an international context.

\subsection{The network model of internationalization}

In the network model of internationalization (Johanson \& Mattsson, 1988), internationalization is related to the development of network ties with other firms belonging to a network in a foreign market. These ties between firms in different markets act as bridges facilitating foreign market entry (Chetty \& Blankenburg Holm, 2000; Johanson \& Vahlne, 1990). The model proposes that a firm can compensate for its limited resources, either by developing its position in an existing network, or by establishing new ties (Johanson \& Mattsson, 1988). In networks, common interests motivate firms to develop and maintain network ties with each other, because such ties are of mutual benefit (Johanson \& Mattsson, 1988; Johanson \& Vahlne, 2003). In foreign markets, a firm can have ties with different types of actors, for example with customers, distributors, suppliers, competitors, non-profit organizations, and bodies in public administration.

Within the literature, the term "network" is utilized in several ways in order to represent connections between actors that can be individuals or organizations (Coviello \& Cox, 2006). Ellis (2008) noted that research utilizing the network model of internationalization had shed light on the interaction between organizations. However, important social exchanges at the level of the individual entrepreneur have been ignored (Ellis, 2008). Since it is the entrepreneur, not the organization, that recognizes opportunities, it is important to study opportunity recognition at the individual level (Chetty \& Blankenburg Holm, 2000; Ellis, 2008). In the present study, individual-level network-tie analysis is applied to clarify how family SMEs recognize international opportunities within social interaction.

\subsubsection{Different types of network ties}

Network ties between firms or individuals have been categorized in a variety of ways. In this study, network ties are divided into formal ties, informal ties, and intermediary ties. A formal tie refers to an existing tie between individual business partners (Adler \& Kwon, 2002; Coviello \& Munro 1997; Ojala, 2009) where products or services are exchanged by means of money or barter (Adler \& Kwon, 2002). 
However, it can be argued that these relationships are also embedded within social ties and are essentially social (Adler \& Kwon, 2002; Granovetter, 1985). Informal ties, for their part, are related to social relationships, for instance with friends and family members (Coviello, 2006; Krackhardt \& Hanson, 1993; Larson \& Starr, 1993). However, the boundary between the formal and informal ties is not always clear. As Larson and Starr (1993) note, informal ties may become formal and vice versa. In the intermediary tie, there are no existing business transactions between the seller and the buyer (Ojala, 2009). However, there is a third party, such as an export promotion organization or an organizer of exhibition, and that party forms a context facilitating the establishment of the network tie between the buyer and the seller. These third parties may, consequently, initiate international business activities between the seller and the buyer (Oviatt \& McDougall, 2005). Taken as a whole, these categories are not mutually exclusive since they develop over time. Nevertheless, in this study, we shall categorize the tie on the basis of the particular situation in which the entrepreneur recognized the international opportunity.

\subsubsection{Strength of ties}

In the social sciences, the strength of network ties is categorized as either strong or weak (Granovetter, 1973). The strength of the tie is not dependent on whether the tie is formal, informal or intermediary: Söderqvist and Chetty (2009) found that both strong and weak ties can exist in different types of relationships. Hence, although strong ties may commonly be related to informal ties, this is not always the case: these informal ties can also be weak. For instance, Hofferth et al. (1999) found that informal ties between family members and/or friends were not always strong, since in some occasions they did not provide the support that was needed.

In previous research, the strength of tie has been considered from a number of perspectives, including the following: closeness (Marsden \& Campbell, 1984), trust (Elg, 2008; Jack, 2005; Morgan \& Hunt, 1994; Singh, 2000), mutual respect (Jack, 2005), and commitment (Hite, 2003: Morgan \& Hunt, 1994). As was pointed out by Marsden and Campbell (1984), the use of frequency and duration as a measure of the strength of a tie can be misleading, and hence these variables are not applied here. Using a modification of the definition provided by Söderqvist and Chetty (2009), in the present research a strong tie is defined as one which is close, and which is based on trust, mutual respect, and commitment. By contrast, a weak tie is "a superficial tie not yet based on strong trust and where the parties do not know each other well and are not emotionally close to each other" (Söderqvist \& Chetty, 2009, p. 9).

The number of strong ties that an individual can have is limited because of the maintenance costs, and the time requirements associated with close ties (Singh, 2000). By contrast, the number of weak ties can be high, due to the fact that weak ties do not require high maintenance or time. Although termed "weak", weak ties can significantly help an entrepreneur in accessing valuable information (Granovetter, 1973; Singh, 2000). Granovetter (1973) argues that weak ties act as bridges to information that is not available through an entrepreneur's strong ties. This is because entrepreneurs interact with weak ties only occasionally; hence weak 
ties can actually provide information that is more unique than that available from strong ties (Singh, 2000). This is also in line with the arguments of Burt (2004) to the effect that new ideas tend to emerge through weak ties between separate social networks. However, Granovetter (1992) takes the view that the emotional bonds of strong ties increase the willingness to offer assistance to actors within a network. In addition, strong ties contain more trust, and are more easily available than weak ties (Granovetter, 1992). Trust is generally based on experience (cooperation history) and continuous investments in learning in the relationships. Partner's general reputation for being trustworthy affects the formation of trust and so do the focal firm's earlier experiences from dealing with the partner and the strategic disadvantages that the partner would suffer by behaving opportunistically (Elg, 2008). Trust increases the willingness to offer advice and to provide valuable information (Singh, 2000). In this study, the analysis of the strength of the tie is based on qualitative rather than quantitative criteria. Hence, a network tie is defined as strong if the interviewees have described it as a close, trustworthy, and respectful relationship with mutual commitment at the time of the international opportunity recognition.

\subsubsection{Activeness}

The formation of network ties with other actors can be active or passive. According to Johanson and Mattsson (1988), active networking means that the initiative is taken by the seller. Thus, an entrepreneur will proactively search for new network ties or actively utilize existing networks. In reactive networking, by contrast, the initiation comes from the buyer (Johanson \& Mattsson, 1988). This means that an entrepreneur will reactively respond to initiations from his/her existing network, or else that the initiative comes from outside an existing network. Hence, relationships can start based from a systematic search for a suitable partner or else as the result of ad hoc events, such as unplanned meetings (Johansson \& Vahlne, 2006). In the present study, the level of the activeness of an entrepreneur was analyzed as a continuum, with reactive and proactive levels forming the opposite ends. If the entrepreneur merely reacted to an initiative from outside, the level is regarded as reactive; if (s)he did something in order to internationalize (for instance attended international trade exhibitions), the activity is regarded as something in between reactive and proactive; if the entrepreneur proactively looked for networks in order to enter the French market, the level is regarded as proactive.

\subsection{Internationalization of family SMEs}

Family involvement in management has been seen as factor tending towards caution in the internationalization processes of family firms (Claver et al., 2008; Kontinen \& Ojala, 2010). Hence, the internationalization of family firms mainly follows a stepwise internationalization process - although some family firms may internationalize rapidly to several different countries, for instance after a generational change (Graves \& Thomas, 2008). Researchers have found that family firms are less likely to internationalize than their non-family firm counterparts (Fernandez \& Nieto, 2005; Graves \& Thomas, 2006). This has been thought to be due 
to their limited growth objectives (Donckels \& Fröhlich, 1991), to avoidance of risk (Claver et al., 2008), and to restricted financial capital (Gallo \& Pont, 1996). In addition, there could be a connection to limited managerial capabilities (Graves \& Thomas, 2006) and to a lack of bridging network ties (Graves \& Thomas, 2004).

As regards networking, family SMEs are less likely to form networks with other businesses than are non-family SMEs (Graves \& Thomas, 2004; Roessl, 2005). This can be seen as a consequence of the strong internal ties of family firms - a phenomenon also termed "family capital" (e.g. Arregle et al., 2007; Salvato \& Melin, 2008). Family firms are oriented towards personal relationships, with a focus on interpersonal trust (Roessl, 2005). The internal ties between family members are extremely strong and they naturally affect decisions on the firm's strategy, operations, and administrative structure (Chrisman et al., 2005). However, close networks do not result in more rapid internationalization; indeed, they can become a liability, hindering the flow of information and blocking links to new contacts (Musteen, Francis \& Datta, in press). It should be noted that bridging or external ties, formed between the employees of a firm and outsiders, are also important for family firms (Arregle et al., 2007), especially in the context of internationalization, since it is via these ties that information from outside the firm may be gained.

\subsection{International opportunity recognition}

Several studies have acknowledged the critical role of opportunities in the entrepreneurial process (Ozgen \& Baron, 2007; Shane, 2000; Shane \& Venkataraman, 2000). However, although opportunities may indeed exist, they can be exploited only if an entrepreneur recognizes the opportunity and understands its value for further business (Shane \& Venkataraman, 2000). Information plays a central role in opportunity recognition (Ozger \& Baron, 2007; Shane, 2000; Shane \& Venkataraman, 2000), and entrepreneurs can get access to such information through network ties (Singh, 2000). The crucial role of an entrepreneur's network ties (Chandra et al., 2009; Crick \& Spence, 2005; Ellis, 2008; Ozgen \& Baron, 2007; Singh, 2000) is due to the fact that the size of an entrepreneur's network is positively related to opportunity recognition. These ties increase the possibility of getting information on new opportunities (Burt, 2004; Granovetter, 1973), with the information tending to arrive via links from separate social networks (Burt, 2004) and weak ties (Singh, 2000).

There is little doubt that opportunity recognition is also related to success in international markets, and further, to the speed of internationalization (Chandra et al., 2009; Dimitratos \& Jones, 2005a; Hohenthal et al., 2003; Oviatt \& McDougall, 2005). In the Uppsala model, Johanson and Vahlne (1977, p. 27) note that "knowledge of opportunities or problems is assumed to initiate decisions" related to foreign market entry and foreign operations. McDougall et al. (1994) have argued that opportunities in foreign markets can be recognized through the use of competencies unique to entrepreneurs, involving networks and earlier experiences. Ellis (2008), too, has found that network ties play an important role in international opportunity recognition. In line with Ellis (2008, pp. 3-4), international opportunity 
recognition is defined here as "the chance to conduct exchange with new foreign partners".

Both formal ties with business partners and informal ties with friends serve as an important source of knowledge related to international opportunities (Child et al., 2002; Coviello, 2006; Ellis, 2008; Johanson \& Mattsson, 1988; Ojala, 2009). For instance, Child et al. (2002) found that the foreign expansion of Hong Kong firms was facilitated through managers' formal networks with previous business partners, and through informal networks with trusted friends. This is line with the opinion of Ellis (2000), that foreign market opportunities are commonly acquired through existing network ties. However, Crick and Spence (2005) found that after the initial entry into foreign markets, the importance of existing networks for recognizing opportunities decreased. This would suggest that SMEs have to identify and implement new opportunities by forming actively new network ties.

Intermediary ties such as professional forums (Ozgen \& Baron, 2007) and trade exhibitions (Ellis, 2008; McAuley, 1999; Meyer \& Skak, 2002; Reid, 1984) have also been found to be sources for information that can facilitate international opportunity recognition. Yet the role of exhibitions as a source of social ties is complex; it appears that the communicated awareness of the opportunities cannot easily be attributed to a buyer, a seller, or a third party (such as a government agency) (Ellis, 2000). Hence, Ellis (2000) suggests that it is appropriate to treat exhibitions as a special kind of initiation scenario. The unique role of exhibitions is consistent with the views of Reid (1984) and McAuley (1999), who found that participation in international exhibitions generates more information concerning international opportunities than any other information source. For their part, Ozgen and Baron (2007) found that the extent of network ties with mentors and informal industry networks was positively related to opportunity recognition; by contrast, network ties with family members and close friends did not increase the ability to recognize new opportunities. It was suggested that this could be due to the more limited industry-specific knowledge and experience of family members and close friends.

An empirical study conducted by Agndal et al. (2008) suggested that both direct (cf. strong ties) and indirect (cf. weak ties) ties are important when SMEs recognize opportunities for foreign market entry. This is in line with a recent study of Chandra et al. (2009) indicating the important role of weak and strong ties when firms initially recognize international opportunities. It appears that weak ties can enable the acquisition of marketing knowledge by connecting different knowledge networks; by contrast, the usefulness of strong ties seems to lie in the passing of information to the relevant persons (Chandra et al., 2009). Although both weak and strong ties may be considered equally important in international opportunity recognition, Söderqvist and Chetty (2009) found that stronger ties were more often used in the early internationalization phase. This was because of mutual trust, commitment, openness, and the generosity of close ties.

Firms can expand their international operations through a combination of searches and accidental opportunity recognitions (Hohenthal et al., 2003). The importance of active networking for foreign market entry has been highlighted in several studies (Crick \& Spence, 2005; Ojala, 2009). Ojala (2009) found that SMEs 
without suitable network ties proactively form new ties with a view to achieving foreign market entry. On the other hand, studies have also indicated the importance of reactive networking for foreign market entry (Crick \& Spence, 2005; Ellis, 2000, 2008; Johanson \& Vahlne, 2003). For instance, Crick and Spence (2005) found that several SMEs in their study entered new countries by receiving unsolicited orders and, in this way, reactively entered new markets.

\subsection{Summary}

Network ties have been regarded as extremely important for international opportunity recognition. Research on this area has been carried out in relation to (i) types of network ties (Child et al., 2002; Coviello, 2006; Ojala, 2009), (ii) strength of network ties (Agndal et al., 2008; Chandra et al., 2009; Crick \& Spence, 2005), and (iii) networking activeness (Crick \& Spence, 2005; Ellis, 2000; Ojala, 2009). However, it remains unclear how each of these perspectives explains the phenomenon, taken as a whole. Furthermore, there has been no research on network ties among family SMEs in relation to international opportunity recognition. From earlier studies, it appears that the internationalization of family SMEs may differ from the internationalization of SMEs in general (see e.g. Fernandez \& Nieto, 2005; Graves \& Thomas, 2006). For this reason, the present study seeks to clarify how these three perspectives explain the international opportunity recognition of family SMEs, and the ways in which the network ties in the international opportunity recognition of family SMEs may differ from those of SMEs overall. Figure 1 illustrates the setting of this research.

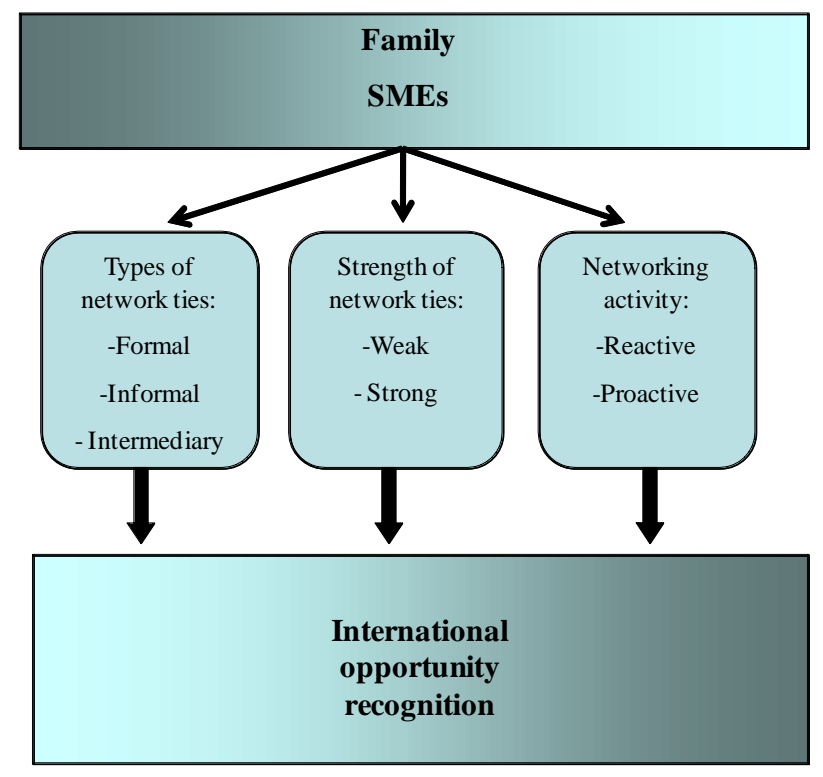

Figure 1

Preliminary theoretical approach. 


\section{Methodology}

Given the current limited understanding of opportunity recognition among family SMEs, it appeared that a qualitative research method would be the most appropriate for the study reported here. We therefore utilized a multiple case study approach similar to the methodology introduced by Eisenhardt (1989) and Yin (1994). The case study method makes possible an in-depth investigation, with explanations of cause-and-effect relationships. It further allows the usage of replication logic regarding the phenomenon in question, enabling researchers to identify the subtle similarities and differences that are present within a collection of cases (Eisenhardt, 1989; Yin, 1994). The case study method is also relevant when the study covers a real-life environment in which a particular action (such as opportunity recognition) takes place (Yin, 1994). Thus, Shane (2000, p. 453) argues that the case study method allows the investigation of opportunity recognition in a situation where "all of the relevant behaviors cannot be manipulated through experimental design."

The research setting for this study consisted of eight Finnish family firms operating in the French market, but with different modes of operation (see Table 1). Finland was chosen as the country of origin due to its small and open economy with a very limited domestic market (OECD, 1997). In countries where the domestic market size is small, internationalization is an important growth strategy, forming part of efforts to guarantee long-term survival (Autio et al., 2000; Sapienza et al., 2006). The choice of the French market as the context made possible the investigation of opportunity recognition in a particular context, one that would be similar for all the firms involved in the study (cf. Shane, 2000) - bearing in mind that laws, regulations, and customs may well vary in different markets (Shrader et al., 2000). Despite its geographical closeness to Finland, France is culturally/psychically different from Nordic and English-speaking countries (Ronen \& Shenkar, 1985; Trompenaars \& Hampden-Turner, 1997), and hence running a business there often involves cultural confrontations. For instance, in Trompenaars' and Hampden-Turner's (1997) seven-scope cultural model, Finland and France are positioned at opposite ends in several cultural classifications. Moreover, in a study on communication in Finnish-French mergers and acquisitions, Irrman (2006) observed that the Finns and the French had many conflicts due to their cultural differences, and especially to their differing ways of communicating. Clearly, ways of avoiding/resolving conflicts need to be found, since France is a very important market - the third largest economy (GDP) in Europe and the eighth largest economy in the whole world (CIA, 2010).

In this study, a family firm was defined as a firm in which the family (i) controls the largest block of shares or votes, (ii) has one or more of its members in key management positions, and (iii) has members of more than one generation actively involved with the business. This definition is based on the two criteria of ownership and management presented, for instance, by Graves and Thomas (2008), and with the notion of continuity presented e.g. by Zahra (2003). The size of the firm was also specified. All the case firms fulfilled the criteria of the Finnish government and the 
EU for SMEs, since they had 250 or fewer employees (OECD, 2003). We also specified the industry: all the case firms were from the manufacturing sector.

The number of cases fits with the view of Eisenhardt (1989), who recommended using four to ten cases. Suitable case firms were sought out from different databases, including Finnish export statistics, the French-Finnish Chamber of Commerce, and Finpro Paris. We identified six SMEs that had direct operations in France, five of which are included in this study. The remaining three cases were family SMEs that had indirect operations (direct export) in France. As advised in the study of Eisenhardt (1989), the case firms for our study were selected for particular theoretical reasons rather than on the basis of random sampling.

Table 1

Information on the case firms.

\begin{tabular}{|c|c|c|c|c|c|}
\hline & $\begin{array}{l}\text { Number of } \\
\text { employees }\end{array}$ & $\begin{array}{l}\text { Year of } \\
\text { establishme } \\
\text { nt }\end{array}$ & Industry segment & $\begin{array}{l}\text { Start of } \\
\text { internationalizatio } \\
\mathrm{n}\end{array}$ & Operations in France \\
\hline Firm A & 249 & 1876 & Industrial furniture & 1970s & $\begin{array}{l}1982 \text { direct export } \\
1984 \text { sales subsidiary }\end{array}$ \\
\hline Firm B & 18 & 1923 & Wooden toys & 1929 & 1968 direct export \\
\hline Firm C & 200 & 1967 & $\begin{array}{l}\text { Machines for forestry and } \\
\text { agriculture }\end{array}$ & 1979 & 1997 sales subsidiary \\
\hline Firm D & 20 & 1973 & Log houses & 1990s & $\begin{array}{l}1998 \text { direct export } \\
2002 \text { representative }\end{array}$ \\
\hline Firm E & 140 & 1972 & Packaging material & 1980s & $\begin{array}{l}1989 \text { direct export } \\
2006 \text { production subsidiary }\end{array}$ \\
\hline Firm F & 40 & 1988 & $\begin{array}{l}\text { Pipettes and analyzing } \\
\text { systems }\end{array}$ & 1991 & $\begin{array}{l}1991 \text { production/sales } \\
\text { subsidiary }\end{array}$ \\
\hline Firm G & 30 & 1978 & Fire safety equipment & 1980 & $\begin{array}{l}1990 \text { import } \\
1991 \text { direct export }\end{array}$ \\
\hline Firm $\mathrm{H}$ & 150 & 1955 & Sauna stoves and equipment & $1990 \mathrm{~s}$ & 1993 direct export \\
\hline
\end{tabular}

We used multiple sources of information to gather data from each case firm. The main form of data collection was in-depth interviews conducted with the ownermanagers and persons in charge of international affairs. Altogether, 16 semistructured open-ended interviews were conducted in 2004 and in 2008-2009, with two informants from each firm. The interviewees were selected from those persons who had most in-depth knowledge concerning internationalization and operations in France, and they included executives (entrepreneurs), managing directors, managers of international affairs and sales administrators. The questions were designed to be broad and open-ended, with a view to gauging individual opinions. This made it possible to ask "main" questions and then to pose further, more detailed questions (Yin 1994).

The interviewees were first asked to describe their business in general, thereafter their operations related to internationalization as a whole, and from that their business as it related to internationalization in France in particular. On the basis of general information on entry to the French market, more detailed questions were then asked about the following issues: (i) important persons, firms, or organizations that influenced the entry to France, (ii) the nature and development of network ties in relation to the French entry, and (iii) the firm's activeness in pursuit of entry to France. In the interview process, we focused on the focal ties connected to market entry in France. The focal tie refers here to the most important contact (see Anderson et al., 1994) of the entrepreneur, the one that opened the firm's path to the 
market. In all the case firms, the entrepreneur was personally involved in the international opportunity recognition. The second interview from each case firm made it possible to validate the focal ties involved in the international opportunity recognition and to deepen understanding of the phenomenon. Because the interviews focused on entrepreneurs' past experiences, we followed the guidelines for retrospective studies given by Miller et al. (1997). Hence, we (i) compared information provided by the informants, (ii) asked about concrete events and facts, (iii) encouraged informants to give precise information rather than past opinions or beliefs, and (iv) utilized the written material of the firm to facilitate the recall of past events.

All the interviews (lasting 60-90 minutes) were digitally recorded and transcribed verbatim. A second listening was carried out to ensure correspondence between the recorded and the transcribed data. The complete case reports were then sent back to the interviewees for comment, and any inaccuracies they noticed were corrected. In addition, e-mail communication was used to collect further information and to clarify inconsistent issues if necessary. A further step at this point was to look at many types of secondary information sources (websites, annual reports, etc.). By comparing the interview data with other documents from the case firms, we conducted triangulation of the information (Miles \& Huberman, 1994). This increased the validity of the interview data, and enabled us to formulate further questions to clarify incoherent information (Yin, 1994).

In the data-ordering phase, a detailed case history of each firm was drawn up, based on interviews and written documents. As Pettigrew (1990) has noted, organizing incoherent aspects in chronological manner is an important step in understanding the causal links between events. In the data analysis phase, we used cross-case pattern searching. The unique patterns of each case were identified, and similar patterns were categorized under themes related to the research questions in this study. In addition, checklists and event listings were used to identify critical factors related to determinants that could contribute to network ties in opportunity recognition (Miles \& Huberman, 1994). Finally, the emergent data was compared with previous studies, indentifying both conflicting and similar findings.

\section{Findings}

In this section we shall present the network ties through which the opportunity to enter France was recognized by the individuals belonging to the case firms. The findings here are generally presented at firm-level. This corresponds to the approach taken, for instance, by Chetty and Blankenburg Holm (2000), Coviello (2006), and Coviello and Munro (1997), who interviewed managers and reported the findings at firm level.

We shall first of all classify the network ties as formal ties, informal ties, and intermediary ties. Secondly, we shall categorize the ties present in the international opportunity recognition as strong or weak. Thirdly, based on the literature on the topic, we shall consider whether the networking activeness of the case firms can be seen as proactive or reactive in respect of their search for opportunities for French market entry. This will allow us to consider network ties in the context of 
opportunity recognition from various perspectives and, hence, increase our understanding of the phenomenon. Notice that the type of network tie is related to the context of the network tie (informal, formal, intermediary), whereas the strength perspective involves the level of trust and emotion in the ties. The level of activeness, for its part, adds to the picture of network ties in opportunity recognition, demonstrating further the attitude of the firms concerned towards the formation of network ties.

\subsection{Types of networks}

As Table 2 illustrates, the network ties involved in the international opportunity recognition of family SMEs were intermediary ties, formal ties, and informal ties. It is interesting that none of the informal ties was a family-based tie. Formal ties were present in the opportunity recognition of Firms $C$ and G. In Firm G, the opportunity to enter France was perceived via a French supplier from whom Firm G imported various components. After one year of cooperation, this French partner asked if Firm $G$ wished to export some items to France, on the grounds that the partner's firm needed the kinds of components that Firm G produced. This, then, was the main context for opportunity recognition: an existing, formal tie within the French market.

\section{Table 2.}

Types of network tie involved in the recognition of opportunities in the French market.

\begin{tabular}{llll}
\hline & Formal & Informal & Intermediary \\
\hline Strong & $\mathrm{C}, \mathrm{G}$ & $\mathrm{F}$ & \\
Weak & & $\mathrm{D}$ & $\mathrm{A}, \mathrm{B}, \mathrm{E}, \mathrm{H}$ \\
\hline
\end{tabular}

In the case of Firm C, one of C's Finnish subcontractors, having had a couple of years of domestic cooperation with Firm $C$, had agreed to work in France as an entrepreneur (with two other men) supplying forest machinery provided by the firm. Firm $C$ had ordered a market research plan and knew there was potential for them. Hence, they started to plan a strategy to access the market. The subcontractor came to be thought of as having the necessary qualities and became the most important tie facilitating French entry.

We looked for and found in Finland a youngish, eager entrepreneur, who worked as our subcontractor. He went off to France with two other men to work as an entrepreneur with our machinery. They knew that they could earn more there in France and that motivated them, as well as the fact that we sold the forest machinery at a very reasonable price [...] That is how we conceived the matter: we knew on the basis of market research that there was potential in France: they needed forest machines.

In Firms $\mathrm{D}$ and $\mathrm{F}$, the essential network tie in the French opportunity recognition was informal. In the case of Firm D, the informal network tie that was essential in the opportunity recognition was a new one. A French national living in Finland happened to run into a representative of Firm D while he was presenting one of D's $\log$ houses. This entrepreneur insisted that he was extremely keen on exporting the 
log houses to France, since he saw the log houses as having potential in the French market. After some negotiations, an agreement was reached, despite the fact that Firm D had not previously had any plans to enter a new market.

We had no plan to go to France. My colleague just met this French guy by chance. He said that he wanted to sell our log houses in France. He saw immediately that there was a huge potential for them in France. [...] Well, then I went to see him and, after some negotiations, said okay, just go ahead and start selling our log houses. I didn't need to invest any money on this attempt, so I didn't have much to lose.

In the case of Firm F, the entrepreneur in question had had a good friend and previous business partner in France, having operated in France with his previous firm. When Firm F was established, previous business partners from different countries (not just France), were enthusiastic about starting up foreign subsidiaries for entrepreneur F's new firm. Hence, in Firm F, the most significant tie was an existing, informal one; it had initially been a formal tie, but over ten years it had developed into a close friendship.

In four cases (in Firms A, B, E, and H), the ties essential for opportunity recognition were formed at international trade exhibitions; hence they were ties mediated by the trade fair organizers (as a third party). All of these firms had been looking for suitable business partners in various trade exhibitions for some years, but none of them had focused solely on finding French partners, and, indeed, had no specific target markets in mind. A particularly important aspect in establishing a tie mediated by the trade exhibitions was a feeling concerning the right nature of the tie. In this respect Firm $A$ is a good example. The firm had launched a new product family and was looking for new markets. The meeting with the future retailer and business partner was described thus:

In those international exhibitions we met many kinds of potential cooperators from different countries. This French partner seemed very pleasant and trustworthy and showed genuine interest in our products. [...] Our product suited their product range perfectly. We had a new, innovative product that other European firms imitated later on and it was of great interest for this retailer. We felt this was a good opportunity, and we were even happier when this partner contacted us himself soon after the exhibitions, and our cooperation started soon after that.

Hence, Firm A became interested in entering France, because a French trustworthy partner was found in the exhibitions. All in all, the entrepreneurs and employees in these firms (A, B, E, and $\mathrm{H})$ trusted their feelings and instincts regarding new ties. Of course, it was important that the tie should be suitable in commercial terms, too. The international sales manager of Firm B, currently exporting to several countries around the world, described the importance of trade exhibitions for their firm as follows:

Trade exhibitions are extremely important for $u s$, that is where all our contacts are made. And that is where we also met our future French agent. We already had business in some countries in Central Europe, and had in mind that France might be among the potential markets, too. And we have found dozens of new French candidates ever since in those trade exhibitions. Last year it was our $41^{\text {st }}$ time there... But we still cooperate with our first contact and have no other retailers in France. 
From this one can see that Firm B conceived of France as a possible market, because the firm had no business operations there at that point. Throughout its history, the strategy of Firm B has been to use only industry exhibitions as a means of finding new partners. Furthermore, the firm has maintained very long-lasting partnerships: they still have the same French retailer after more than forty years of cooperation.

\subsection{Strength of ties}

Concerning the strength of the network ties, in five out of eight case firms, the network ties essential for French opportunity recognition were weak (see Table 2). These weak ties were linked to international exhibitions (Firms A, B, E, and H) or to an unsolicited order (Firm D). However, these weak ties were not weak in any absolute sense, from the perspectives of intimacy and emotional intensity - this despite the fact that there were no reciprocal services in the background and the ties were newly established. In describing their new French cooperators, the interviewees described how the persons they started their cooperation with were agreeable, and how they trusted their instincts as to whether the tie "felt good". The selection criteria for a good cooperator were not really based on the formal merits (qualifications or experience) of the person; it was rather a matter of personality. Many of the people the entrepreneurs and employees met in the exhibitions were not of interest to them. This could be because they did not seem entirely trustworthy, and/or because they had the wrong product. The export manager in Firm $\mathrm{H}$ explained his choice of cooperators in the following manner:

And also with our first French retailer, someone we met in the international trade exhibitions of our field, we saw in the first face-to-face meeting after the exhibitions that he was a suitable person and motivated to sell our products. We get several offers of cooperation every week from retailers, including people in France, every month. What we do depends on the person and his/her motivation to sell our products. If the first meeting is promising we continue with the discussion and may get a new retailer. Quite often, we know very soon after we meet the potential retailer that it will not work.

Another example is Firm D, in which a French entrepreneur living in Finland succeeded in persuading D of the potential of their log houses in France. The entrepreneur in Firm D made an agreement with this weak tie after a short conversation, since there was no financial risk for the firm and the French contact seemed highly motivated to sell the firm's log houses in France and was a "good guy". The fact that the French contact took out a large personal loan to carry out his ideas for selling the log houses naturally assured Firm D of the rightness of the opportunity. Although the entrepreneur in Firm D did not invest any money on French entry, he invested a lot of time and effort. It is interesting that in all these firms this weak tie became fairly strong very quickly, on the basis of mutual trust and interest in cooperation. It seems to be the case that in family-owned SMEs, the entrepreneurs have the ability to focus on the ties very intensely if they choose to do so, and this facilitates a quick enhancement of the tie from weak to strong. The entrepreneur in Firm D explained it in the following way: 
I got a phone call and agreed to chat with him because of it. After the first meeting we agreed that he would start selling our log houses in France. [...] Being a small family-owned firm, it was easy to make a quick decision to launch business operations in France. This French person invested a lot of his own time and money to start the business in France, he learned the Finnish language and was very motivated in other ways, too. Based on this and the sales trips we undertook together to France, where we faced and also solved many problems, it was easy for me to trust him more and more.

Three firms (Firms C, F and G) were able to utilize strong ties for French opportunity recognition. In all three cases, these strong network ties were originally business partners, but in the case of Firm F, this business partner had become a friend while they were previously doing business together. The tie between the entrepreneur and the French friend was extremely strong: they had known each other for more than ten years, and had cooperated in business for more than five years. The entrepreneur in Firm F described the tie and the start of the cooperation in these terms:

We were good friends. It was very natural that we started cooperation after I launched my new firm. Well, it happened spontaneously, because we were such good friends. I do not even know who asked first, me or him. He wanted to work for me and not for my previous firms, which had been taken over, so he resigned right away when he heard about my new firm. [...] During all these years, I have got to know him extremely well. We can trust each other 100\%, we have respect for each other's opinions, have similar kinds of values in life and are interested in similar kinds of things. [...] We do not communicate that often, but we can always proceed from where we left off last time.

Hence, the entry to France was a natural first step in internationalization for the entrepreneur of Firm F, since he knew this French friend so well and trusted him completely. Furthermore, the French friend was willing to cooperate with this entrepreneur, because he knew that in this family-owned firm the decision power was in good hands, and that values other than just making a quick profit were important to the firm. They had also similar kinds of interests and values and a lot of respect for each other. In the case of Firm G, there was a strong tie between Firm $G$ and the French importer, as this French firm was able to provide the $G$ with good-quality components at a reasonable price for a period of one year. The ownermanager of Firm $G$ described the personality of their French cooperators in a positive manner.

They are very pleasant people. They have good products and we have been able to trust their deliveries, although sometimes they are a bit late. Yes, they are nice, and when we visited them in France, they took very good care of us. When they asked for components, it was natural to start exporting them after our cooperation in importing.

Exporting was a natural continuation to the tie between the importer and Firm G, based on G's knowledge of the importer and in the trust that was built up regarding the importer's products and staff. However, the level of emotional intensity or intimacy was not as high as in the case of Firm F, where there was a long history of 
cooperation and deep friendship. In the case of $G$, the parties did not meet many times and were not doing business so intensely.

In the case of Firm C, the Finnish subcontractor enabling French entry was seen as having potential because of previous successful cooperation, his young age, and his willingness to earn money. When Firm $C$ was considering entry into the French market (in conjunction with the subcontractor and his friends) the subcontractor was also motivated by the acquisition of new forest machinery at a reasonable price. Hence, this tie was not especially strong in any emotional sense; nevertheless, the subcontractor was regarded as a "good guy", and there were several of successful reciprocal services in the background.

\subsection{Networking activeness in the firms}

In their pursuit of the French market, only in Firm $C$ there was a strategic desire to enter France. In the remaining firms (whose backgrounds are described in more detail below), French opportunities were not searched on any unique basis, and they might actually not be looking for new international opportunities at all. The networking activeness in the case firms in their attempts to enter the France market was assessed in the form of a continuum (see Figure 2). In seven out of eight case firms, the approach was more reactive than proactive. They reacted to the opportunities that arose by meeting people who would promote entry to France. Firm D was the most reactive firm, as it had no intentions to internationalize. It merely reacted to an unsolicited order which launched their operations in France.

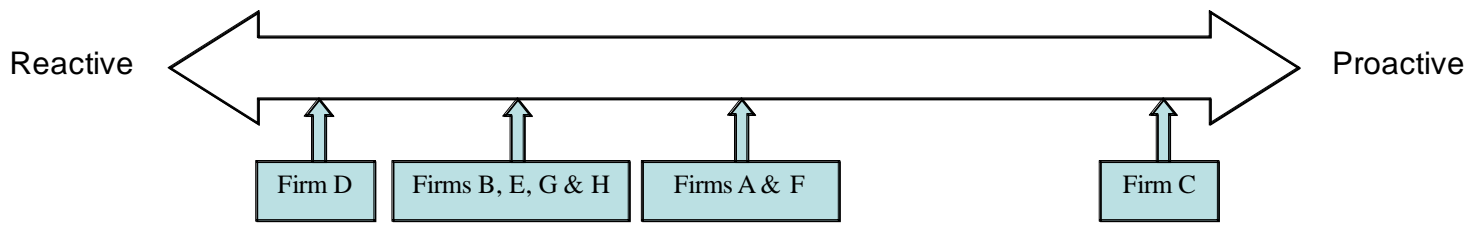

Figure 2

Activeness in the case firms in their search for French opportunities.

In the case of Firms B, E, G, and H, the approach to the French market can be considered fairly reactive. Nonetheless, they would not be not placed on the furthest edge of the continuum, since they had a general will to expand their business; moreover, they traveled to international exhibitions (Firms B, E, and H) or had a background import business (Firm G). This indicates that they had considered the need for new international markets, with the possibility of following up the matter if they happened to see good opportunities. The entrepreneur in Firm G explained this in the following way:

We once tried to get a French connection while we were trying to win a contract for a shipping company. It did not succeed, as we did not find anything there. But we had a new opportunity as our French importer suggested that we could start exporting to France. [...] We have not got the money or courage to invest in big internationalization attempts, but in this way it was very convenient. 
Firm A was active in its general attempts to internationalize, since it had launched a new product family and wanted to move into Europe. Nevertheless, it did not search for solely French opportunities; hence it is included in the middle of the continuum regarding French opportunity recognition.

We had launched a new product family and had in mind to start selling it in Europe. In the exhibitions, we looked for potential agents and as one of the most likely ones came from France, we felt that we had found a good opportunity for French entry.

Firm F, too, had background plans to internationalize, but because of the strong network ties of the entrepreneur it did not need to do anything to pursue internationalization at that point. A somewhat reactive attitude was possible because of the opportunity for internationalization offered by the entrepreneur's friends, and by business partners he had cooperated with in his previous firms. On this basis, Firm F can be placed in the middle of the continuum, together with Firm A.

Firm $\mathrm{C}$ is the only firm that can be considered proactive in its approach to moving into the French market: it actively sought out opportunities, in other words people who could start to establish a subsidiary there. In addition, prior to that, it had ordered market research to clarify the potential of the French market.

\section{Discussion}

It seems that although family firms have strong internal ties (Arregle et al., 2007; Salvato \& Melin, 2008), these ties do not enhance their internationalization. Only three out of the eight case firms were able to use their existing formal or informal network ties for their international opportunity recognition, which would suggest that family SMEs have only limited bridging network ties beyond the firm itself. This finding demonstrates a contrast with a number of previous studies on nonfamily SMEs. Coviello and Munro (1995) found that more than half of the software firms they studied obtained their opportunities through existing formal/informal ties, and Bell (1995) found that software SMEs followed their existing domestic networks abroad. Furthermore, Coviello (2006) found that formal (economic) ties dominated at all the stages of internationalization of international new ventures. These differences are all consistent with the view that in the case of family SMEs, a lack of bridging network ties inhibits internationalization, and that family SMEs compensate for their limited bridging network ties by attending international exhibitions where they can form new ties. Network ties mediated by international exhibitions were the source of international opportunity recognition in four case firms. Interestingly, none of the intermediary ties were mediated by, for instance, the export-promoting organizations (cf. Ojala, 2009). It seems that the entrepreneurs in the family SMEs studied here wanted to select their network ties for themselves, based on a feeling of trust (discussed in more detail below). Furthermore, none of the family SMEs utilized family ties in the international opportunity recognition process. Ozgen and Baron (2007) suggested that family ties did not facilitate the opportunity recognition process of information technology firms. However, in the case of family SMEs with strong internal network ties (Salvato \& Melin, 2008), this finding is somewhat surprising, because it could be assumed that family SMEs use 
their strong family ties also in their internationalization. The considerations above lead to the following propositions:

Proposition 1a: In family SMEs, intermediary network ties are a more important source of international opportunity recognition than they are in other types of firm.

Proposition 1b: In family SMEs, the intermediary network ties are most often mediated by international trade exhibitions.

Proposition 2: In family SMEs, informal ties with family members do not generally help in their international opportunity recognition.

In the present study, the ties involved in international opportunity recognition were found to be generally weak, having been formed in international exhibitions, or deriving from an unsolicited order. Interestingly, none of the weak ties were formal, indicating the lack of existing business ties that could be used for internationalization. As regards the new ties, the personality of the potential cooperator was significantly more important than the proven skills or qualifications of the person - and more important also than the target market, as can be seen from the fact that only one of the firms had taken a decision to enter France. In this result one can see a contrast with that of Ojala (2009), who found that the target market was the most important criterion for knowledge-intensive SMEs.

The weak ties of family SMEs quickly developed into strong ties. The family entrepreneurs were willing to put a lot of their own time into developing the ties, once they gained a sense of the goodness of the tie. This might be connected to the strong internal ties of family SMEs - they want to have a similar strong relationship with outside cooperators. There is a contrast here with the findings of Söderqvist and Chetty (2009): in their research, strong ties had a central role in the foreign market entry of SMEs, and the dynamism of the ties was a constant factor, both in the strong to weak and in the weak to strong direction. However, the findings in the present study indicate that family SMEs developed their weak ties into strong ties very quickly, and made efforts to maintain the strength of the ties.

The findings also indicate that the family entrepreneurs in question were fairly fastidious in the weak ties they chose to form, cooperating only with those individuals that they felt were trustworthy - "good people". This finding reveals that family SMEs control their resources by carefully searching for and developing new contacts. This is in line with the general findings of Carney (2005) and Sirmon and Hitt (2003). However, here the importance of this aspect is also highlighted with regard to foreign market entry. When the case firms developed strong ties, the opportunity to enter France became self-evident, because of the trust between the cooperating parties. The decision was taken rapidly, without any need for extensive strategic deliberations. From this, one can derive the following two propositions:

Proposition 3: In family SMEs, international opportunities are more often recognized through weak ties than is the case in other types of firm. 
Proposition 4: In family SMEs, more time resources are dedicated to the rapid development of new weak ties into strong ties than is the case in other types of firm.

It appears that the family SMEs in this study were more reactive than proactive in their attempts to enter the French market - though many of them cannot be regarded as straightforwardly reactive or proactive in this matter, since they had some background plans for growth and internationalization. The rather low level of activeness towards the French market can also be explained by the fact that family entrepreneurs trust their feelings about the rightness of a certain tie. They do not strategically concentrate on the search for ties in a particular market; their motivation derives rather from a strong inner trust in their own firms and, connected with this, a strong need to feel good about the potential and the suitability of their cooperators.

This finding provides an interesting contrast with the findings of Ojala (2009), who observed that knowledge-intensive SMEs (i.e. non-family firms) proactively formed networks, and were willing to enter certain foreign markets with high market potential. The reason for this difference may lie in the fact that family entrepreneurs do not want to take risks in their internationalization process. By and large, they trust their instincts about taking things further (Gallo \& Pont, 1996), concentrating on seizing opportunities that seem to involve trust. Thus, the final proposition is as follows:

Proposition 5: In family SMEs, foreign market selection is more related to reactiveness and less to proactive opportunity-seeking with a particular foreign market in mind.

\section{Conclusions}

This study contributes to the network theory of internationalization in the context of family SMEs and research on international opportunity recognition. It responds to the call for more research on international opportunity recognition (Dimitratos \& Jones, 2005a; Ellis, 2008; Oviatt \& McDougall, 2005; Zahra et al., 2005) and to the need for studies on the importance of network ties in recognizing opportunities for internationalization (Ellis, 2000, 2008; Singh, 2000). We extend the network theory of internationalization by showing that in the international opportunity recognition of family SMEs, new network ties (mainly formed at international trade exhibitions) have a crucial role, whereas family ties are less important. Hence, among family SMEs, international opportunity recognition does not commonly take place through existing network ties. In this regard, we observe a contrast with the knowledgeintensive SMEs studied by Bell (1995) and Coviello (2006), where existing network ties had a more significant role. This can be explained through the limited scope of the networks (Graves \& Thomas, 2004) that the family SMEs could utilize for international expansion. This also supports Granovetter's (1973) views on the importance of weak ties in providing new information. However, we extend the understanding about weak ties in this context by revealing that the possibility to develop a new weak tie into a trustworthy one is particularly important for family 
entrepreneurs in recognizing opportunities for foreign market entry, with a sense of the "rightness" of the tie emerging as essential. Furthermore, our findings indicate that family SMEs are quick to develop their new weak ties into strong ties, and that they make efforts to maintain the strength of such ties. Indeed, the nature of the weak tie is seen as more important than the target country.

However, while contributing to an understanding of the topic, this study also points to aspects requiring further research. The propositions set out in Section 5 need further quantitative testing, since caution has to be applied in generalizing from a limited set of data. Secondly, our research setting delimits the case firms to family-owned SMEs, and to firms entering a particular market. Thus, further studies are needed in relation to the network development, international opportunity identification, and opportunity exploration of early-internationalizing firms, and of firms having different kinds of ownership structures. Studies comparing family SMEs and non-family SMEs could also be insightlful. It would also be of interest to study the international opportunity recognition of firms by comparing two markets, one with higher and another with lower psychic/cultural distance. Thirdly, the focus of this study was solely on opportunities that were actually taken. There is therefore a need for further research on international opportunities that are recognized, but not taken, and the mechanisms according to which international opportunities are taken by some and ignored by others. Fourthly, the importance of trust was highlighted in this study: hence future research might well focus on the precise ways in which trust and commitment are developed in international opportunity recognition. Fifthly, it would be of interest to study how the age of a firm and the level of internationalization affect the international networking activity. Furthermore, here we study family SMEs as a whole: in future research, the role that may be played by differing degrees of family ownership and management on their network formation could be determined. Finally, having only two interviews per firm could be seen as a limitation. However, having regard to the small size of the firms and the role of the persons interviewed, one can see that these informants had the kind of crucial knowledge required for the purposes of this study.

From a managerial point of view, family entrepreneurs with limited networks should concentrate on actively looking for weak ties that will provide them with novel information on international opportunities. Due to the closeness of family members and employees within family SMEs, their internal bonding ties do not generate this kind of information. This study found that trade exhibitions offer a good context for family SMEs to create ties leading to new international opportunities. Another option for networking could be export-promotion organizations that could mediate relationships between family SMEs and potential foreign customers or distributors. It is, however, noteworthy that none of the case firms used the services of export-promotion organizations, despite the fact that some studies have indicated the importance of these organizations for SMEs (see e.g. Ojala, 2009). 


\section{Acknowledgements}

The authors would like to thank Pervez Ghauri, the Editor of International Business Review, and the anonymous reviewers for their valuable comments and suggestions. The research has been generously funded by Foundation for Economic Education.

\section{References}

Adler, P.S. and Kwon, S-W. (2002). Social capital: Prospects for a new concept, Academy of Management Review, 27/1, 17-40.

Agndal, H., Chetty, S. and Wilson, H. (2008). Social capital dynamics and foreign market entry, International Business Review, 17/6, 663-675.

Anderson, J.C., Håkansson, H. and Johanson, J. (1994). Dyadic Business Relationships Within a Business Network Context, Journal of Marketing, 58/4, 115.

Arregle, J-L., Hitt, M., Sirmon, D. and Very, P. (2007). The development of organizational social capital: attributes of family firms, Journal of Management Studies, 44/1, 73-95.

Autio, E., Sapienza, H.J. and Almeida, J.G. (2000). Effects of age at entry, knowledge intensity, and imitability on international growth, Academy of Management Journal, 43/5, 909-924.

Bell, J. (1995). The Internationalization of Small Computer Software Firms: A Further Challenge to "Stage" Theories, European Journal of Marketing, 29/8, 6075.

Burt, R.S. (2004). Structural Holes and Good Ideas, American Journal of Sociology, 110/2, 349-399.

Carney, M. (2005). Corporate governance and competitive advantage in familycontrolled firms, Entrepreneurship Theory and Practic,e 29/3, 249-265.

Chandra, Y., Styles, C. and Wilkinson, I. (2009). The recognition of first time international entrepreneurial opportunities: Evidence from firms in knowledgebased industries, International Marketing Review, 26/1, 30-61.

Chetty, S. and Blankenburg Holm, D. (2000). Internationalisation of small to medium-sized manufacturing firms: a network approach, International Business Review, 9, 77-93.

Child, J., Ng, S.H. and Wong, C. (2002). Psychic distance and internationalization: Evidence from Hong Kong firms, International Studies of Management $\mathcal{E}$ Organization, 32/1, 36-56.

Chrisman, J.J, Chua, J.H. and Steier, L. (2005). Sources and consequences of distinctive familiness: an introduction, Entrepreneurship Theory and Practice, 29, 237-247.

CIA (2010). The World Factbook. Washington DC: Central Intelligence Agency.

Claver, E., Rienda, L. and Quer, D. (2008). Family firms' risk perception: Empirical evidence on the internationalization process, Journal of Small Business and Enterprise Development, 15/3, 457-471.

Coviello, N. (2006). The network dynamics of international new venture, Journal of International Business Studies, 37/5, 713-731. 
Coviello, N. and Cox, M.P. (2006). The resource dynamics of international new venture networks, Journal of International Entrepreneurship, 4/2-3, 113-132.

Coviello, N. and Munro, H. (1997). Network Relationships and the Internationalisation Process of Small Software Firms, International Business Review, 6/4, 361-386.

Crick, D. and Spence, M. (2005). The internationalisation of 'high performing' UK high-tech SMEs: a study of planned and unplanned strategies, International Business Review, 14/2, 167-185.

Dimitratos, P. and Jones, M. (2005a). Future directions for international entrepreneurship research, International Business Review, 14/2, 119-128.

Dimitratos, P. and Jones, M. (2005b) International Entrepreneurial Culture, International Opportunity Perception and Pattern of International Exploitation: Towards an Integrative Model. In P. Ghauri, A. Hadjikhani and J. Johanson (eds.), Managing Opportunity Development in Business Networks, New York: Palgrave, 67-90.

Donckels, R. and Fröhlich, E. (1991). Are family businesses really different? European Experiences from STRATOS, Family Business Review, 12/2, 146-160.

Eisenhardt, K.M. (1989). Building theories from case study research, Academy of Management Review, 14/4, 532-550.

$\mathrm{Elg}$, U. (2008). Inter-firm market orientation and the influence of network and relational factors, Scandinavian Journal of Management, 24, 55-68.

Ellis, P. (2000). Social Ties and Foreign Market Entry, Journal of International Business Studies, 31/3, 443-469.

Ellis, P. (2008). Social ties and international opportunity recognition. Unpublished manuscript, Hong Kong Polytechnic University.

Fernandez, Z. and Nieto, M. J. (2005). Internationalization strategy of small and medium-sized family businesses: Some influential factors, Family Business Review, 18/1, 77-89.

Fernandez, Z. and Nieto, M. J. (2006). Impact of ownership on the international involvement of SMEs, Journal of International Business Studies, 37/3, 340-351.

Gallo, M.A., and Pont, C.G. (1996). Important factors in family business internationalization, Family Business Review, 9/1, 45-59.

Ghauri, P., Lutz, C. and Testom, G. (2003). Using networks to solve exportmarketing problems of small- and medium-sized firms from developing countries, European Journal of Marketing, 37/5-6, 728-752.

Granovetter, M.S. (1973). The Strength of Weak Ties, American Journal of Sociology, 76/6, 1360-1380.

Granovetter, M.S. (1985). Economic Action and Social Structure: The Problem of Embeddedness, American Journal of Sociology, 91, 481-510

Granovetter, M.S. (1992) Problems of explanation in economic sociology. In N. Nohria and R. Eccles (eds.), Networks and organizations, Boston, MA: HBS Press, $25-56$.

Graves, C. and Thomas, J. (2004). Internationalisation of the family business: a longitudinal perspective, International Journal of Globalisation and Small Business, 1/1, 7-27. 
Graves, C. and Thomas, J. (2006). Internationalization of Australian family businesses: A managerial capabilities perspective, Family Business Review, 19/3, 207-224.

Graves, C. and Thomas J. (2008). Determinants of the internationalization pathways of family firms: An examination of family influence, Family Business Review, $21 / 2,151-167$.

Hadjikhani, A., Ghauri, P. and Johanson, J. (2005) Introduction: Opportunity Development in Business Networks. In P. Ghauri, A. Hadjikhani and J. Johanson (eds.), Managing Opportunity Development in Business Networks, New York: Palgrave, 1-24.

Hite, J.M. (2003). Patterns of multidimensionality among embedded network ties: a typology of relational embeddedness in emerging entrepreneurial firms, Strategic Organization, 1/1, 9-49.

Hofferth, S.L., Boisjoly, J. and Duncan, G.J. (1999). The Development of Social Capital, Rationality and Society, 11/1, 79-110.

Hohenthal, J., Johanson, J. and Johanson, M. (2003). Market discovery and the international expansion of the firm, International Business Review, 12/6, 659-672.

IFERA (2003). Family Businesses Dominate, Family Business Review, 16/4, 235-240.

Irrmann, O. (2006). Intercultural communication and the integration of cross-border acquisitions. Doctoral dissertation. Helsinki School of Economics, Helsinki.

Jack, S.L. (2005). The Role, Use and Activation of Strong and Weak Network Ties: A Qualitative Analysis, Journal of Management Studies, 26/6, 1234-1259.

Johanson, J. and Mattsson, L-G. (1988) Internationalisation in Industrial Systems - A Network Approach. In N. Hood and J-E. Vahlne (eds.), Strategies in Global Competition, London: Croom Helm, 287-314.

Johanson, J. and Vahlne, J-E. (1977). The internationalization process of the firm - a model of knowledge development and increasing foreign market commitments, Journal of International Business Studies, 8/1, 23-32.

Johanson, J. and Vahlne, J-E. (1990). The Mechanism of Internationalisation, International Marketing Review, 7/4, 11-24.

Johanson, J. and Vahlne, J-E. (2003). Business Relationship Learning and Commitment in the Internationalization process, Journal of International Entrepreneurship, 1/1, 83-101.

Johanson, J. and Vahlne, J-E. (2006). Commitment and Opportunity Development in the Internationalization Process: A Note on the Uppsala Internationalization Process Model, Management International Review, 46/2, 165-178.

Johanson, J. and Vahlne, J-E. (2009). The Uppsala internationalization process model revisited: From liability of foreignness to liability of outsidership, Journal of International Business Studies, 40, 1411-1431.

Kontinen, T. and Ojala, A. (2010). The internationalization of family businessess: A review of extant research, Journal of Family Business Strategy, 1/2, 97-107.

Krackhardt, D. and Hanson, J. (1993). Informal Networks: The Company Behind the Chart, Harvard Business Review, 71/4, 104-111.

Larson, A. and Starr, J.A. (1993). A Network Model of Organization Formation, Entrepreneurship Theory and Practice, 17/2, 5-15. 
Marsden, P.V. and Campbell, K.E. (1984). Measuring tie strength, Social Forces, 63/2, 482-501.

McAuley, A. (1999). Entrepreneurial Instant Exporters in the Scottish Arts and Crafts Sector, Journal of International Marketing, 7/4, 67-82.

McDougall, P.P., Shane, S. and Oviatt, B.M. (1994). Explaining the formation of international new ventures: The limits of theories from international business research, Journal of Business Venturing, 9/6, 469-487.

Meyer, K. and Skak, A. (2002). Networks, Serendipity and SME Entry into Eastern Europe, European Management Journal, 20/2, 179-188.

Miles, M.B. and Huberman, A.M. (1994) Qualitative Data Analysis: An Expanded Sourcebook. California: Sage Publications.

Miller, C.C., Cardinal, L.B. and Glick, W.H. (1997). Retrospective reports in organizational research: A reexamination of recent evidence, Academy of Management Journal, 40/1, 189-204.

Morgan, R.M. and Hunt, S.D. (1994). The Commitment-Trust Theory of Relationship Marketing, Journal of Marketing, 58, 20-38.

Musteen, M., Francis, J. and Datta, D.K. (in press). The influence of international networks on internationalization speed and performance: A Study of Czech SMEs, Journal of World Business.

OECD (1997). Globalisation and small and medium enterprises (SMEs). Synthesis Report, Vol. 1. France: Organization for Economic Co-operation and Development.

OECD (2003) Officially-supported export credits and small exporters. France: Organization for Economic Co-operation and Development.

Ojala, A. (2009). Internationalization of knowledge-intensive SMEs: The role of network relationships in the entry to a psychically distant market, International Business Review, 18/1, 50-59.

Oviatt, B.M. and McDougall, P.P. (2005). Defining international entrepreneurship and modeling the speed of internationalization, Entrepreneurship Theory and Practice, 29/5, 537-553.

Ozgen, E. and Baron, R.A. (2007). Social sources of information in opportunity recognition: Effects of mentors, industry networks, and professional forums, Journal of Business Venturing, 22/2, 174-192.

Pettigrew, A.M. (1990). Longitudinal field research on change: Theory and Practice, Organization Science, 1/3, 267-292.

Reid, S.D. (1984). Information acquisition and export entry decisions in small firms, Journal of Business Research, 12/2, 141-157.

Roessl, D. (2005). Family Businesses and Interfirm Cooperation, Family Business Review, 18/3, 202-214.

Ronen, S. and Shenkar, O. (1985). Clustering Countries on Attitudinal Dimensions: A Review and Synthesis, Academy of Management Review, 10/3, 435-454.

Salvato, C. and Melin, L. (2008). Creating Value Across Generations in FamilyControlled Businesses: The Role of Family Social Capital, Family Business Review, 21/3, 259-276. 
Sapienza, H.J., Autio, E., George, G. and Zahra, S.A. (2006). A capabilities perspective on the effects of early internationalization on firm survival and growth, Academy of Management Review, 31/4, 914-933.

Shane, S. (2000). Prior knowledge and the discovery of entrepreneurial opportunities, Organization Science, 11/4, 448-469.

Shane, S. and Venkataraman, S. (2000). The promise of entrepreneurship as a field of research, Academy of Management Review, 26/1, 13-17.

Shrader, R.C., Oviatt, B.M. and McDougall, P.P. (2000). How new ventures exploit trade-offs among international risk factors: Lessons for the accelerated internationalization of the 21st century, Academy of Management Journal, 43/6, 1227-1247.

Singh, R.P. (2000) Entrepreneurial Opportunity Recognition Through Social Networks. New York: Garland Publishing.

Sirmon, D.G. and Hitt, M.A. (2003). Managing Resources: Linking Unique Resources, Management, and Wealt Creation in Family Firms, Entrepreneurship Theory and Practice, 27/4, 339-358.

Söderqvist, A. and Chetty, S. (2009). Strength of ties and their role in pre-founding, start-up and early internationalization. Paper presented at $12^{\text {th }}$ McGill International Entrepreneurship Conference, Vaasa, Finland.

Trompenaars, F. and Hampden-Turner, C. (1997) Riding the waves of culture: Understanding cultural diversity in business, (2nd ed.), London: Nicholas Brealey.

Yin, R.K. (1994) Case study research: Design and methods (2nd ed.), Newbury Park, CA: SAGE Publications.

Zahra, S.A. (2003). International expansion of U.S. manufacturing family businesses: The effect of ownership and involvement, Journal of Business Venturing, 18/4, 495-512.

Zahra, S.A., Korri, J.S. and Yu, J.F. (2005). Cognition and international entrepreneurship: implications for research on international opportunity recognition and exploitation, International Business Review, 14/2, 129-146. 